\title{
PENERAPAN MODIFIKASI PERMAINAN BOLAVOLI TERHADAP HASIL BELAJAR SISWA DALAM PEMBELAJARAN BOLAVOLI
}

\author{
Ahmad Yadi Dwi Saputra ${ }^{1)}$, Rubbi Kurniawan ${ }^{2)}$ \\ Pendidikan Jasmani Kesehatan dan Rekreasi \\ Fakultas Pendidikan Ilmu Eksakta dan KeolahragaanIKIP Budi Utomo \\ Email : 1 Ahmadyadi@gmail.com \\ ${ }^{2}$ RubbiKurniawan@ gmail.com
}

\begin{abstract}
ABSTRAK
Salah satu cara untuk menyampaikan pembelajaran yang kreatif dan inovatif adalah dengan cara memodifikasi sebuah pembelajaran agar lebih menarik serta membuat siswa menjadi antusias dan aktif dalam mengikuti pembelajaran pendidikan jasmani, olahraga dan kesehatan. Dengan demikian memodifikasi suatu pembelajaran dapat mempengaruhi hasil belajar siswa. Tujuan dari penelitian ini adalah untuk mengetahui penerapan modifikasi permainan bola voli terhadap hasil belajar siswa dalam pembelajaran bolavoli pada siswa kelas VIII-C SMP Negeri 1 Krejengan Probolinggo.Berdasarkan hasil penelitian, diketahui bahwa penerapan modifikasi permainan bola voli dapat meningkatkan hasil belajar siswa dalam mengikuti pembelajaran pendidikan jasmani, olahraga dan kesehatan dalam aspek kognitif sebesar 22,93\% dan dalam aspek psikomotor sebesar 20,92\%. Peningkatan hasil belajar siswa dari hasil siklus I aspek kognitif diperoleh sebesar $16,70 \%$ dan aspek psikomotor diperoleh sebesar $17,50 \%$. Sedangkan hasil siklus II aspek kognitif diperoleh sebesar $76,70 \%$ dan aspek psikomotor diperoleh sebesar 70,00\%. Sehingga dapat disimpulkan bahwa ada peningkatan yang signifikan melalui penerapan modifikasi permainan bola voli terhadap hasil belajar siswa dalam pembelajaran bolavoli pada siswa kelas VIII-C SMP Negeri 1 Krejengan Probolinggo.
\end{abstract}

Kata Kunci: Modifikasi, Permainan Bolavoli, Hasil Belajar.

\begin{abstract}
One way to convey creative and innovative learning is by modifying a learning to make it more interesting and make students become enthusiastic and active in taking part in physical education, sports and health learning. Thus modifying a learning can affect student learning outcomes. The purpose of this study was to determine the application of modification of volleyball games to student learning outcomes in volleyball learning in class VIII-C students of SMP Negeri 1 Krejengan Probolinggo. Based on the results of the study, it is known that the application of modification of volleyball games can improve student learning outcomes in learning physical education, sports and health in the cognitive aspects of $22.93 \%$ and in psychomotor aspects by $20.92 \%$. Improved student learning outcomes from the results of the first cycle of cognitive aspects obtained by $16.70 \%$ and psychomotor aspects obtained by $17.50 \%$. While the results of cycle II cognitive aspects were obtained at $76.70 \%$ and psychomotor aspects were obtained at $70.00 \%$. So that it can be concluded that there is a significant increase through the application of modification of volleyball games to student learning outcomes in volleyball learning in class VIII-C students of SMP Negeri 1 Krejengan Probolinggo.
\end{abstract}

Keywords: Modification, Volleyball Games, Learning Outcomes 


\section{PENDAHULUAN}

Pendidikan jasmani, olahraga, dan kesehatan bukan berisi materi pembelajaran yang dirancang hanya untuk mengasah kompetensi keterampilan peserta didik, atau mata pelajaran yang membaginya menjadi pengetahuan tentang kesehatan dan keterampilan berolahraga. Pendidikan Jasmani, Olahraga dan Kesehatan merupakan bagian integral dari pendidikan secara keseluruhan, bertujuan untuk mengembangkan aspek kebugaran jasmani, keterampilan gerak, keterampilan berfikir kritis, keterampilan sosial, penalaran, stabilitas emosional, tindakan moral, aspek pola hidup sehat dan pengenalan lingkungan bersih melalui aktivitas jasmani, olahraga dan kesehatan terpilih yang direncanakan secara sistematis dalam rangka mencapai tujuan pendidikan nasional (Kurniawan, 2014).

Modifikasi pembelajaran yang dilakukan oleh guru adalah usaha untuk mewujudkan DAP (Developmentally Appropriate Practice) yang berarti tugas ajar yang diberikan harus memperhatikan kemampuan anak dan dapat membantu mendorong perubahan tersebut (Bahagia dan Mujianto, 2009). Oleh karena itu, DAP harus selalu dijadikan prinsip utama dalam memodifikasi pembelajaran pendidikan jasmani. Esensi modifikasi adalah menganalisa dan mengembangkan materi pembelajaransecara berurutan dalam bentuk aktivitas belajar yang baiksehinggamempermudah siswa dalam proses belajarnya belajarnya (Purwanto, 2011). Cara ini dimaksudkan untuk menuntun, mengarahkan, dan membelajarkan siswa yang tadinya tidak bisa menjadi bisa, dari tingkat yang tadinya rendah menjadi memiliki tingkat yang lebih tinggi (Saputra, 2015).

Pelaksanaan pendidikanjasmani, olahraga dan kesehatan merupakan investasi jangka panjang dalam rangka meningkatkan mutu sumber daya manusia Indonesia (Syamsudin, Haetami, dan Hidasari, 2016).Proses pelaksanaan pendidikan tersebut juga harus diiringi dengan penyampaian pengajaran yang kreatif dan inovatif. Salah satu caranya adalah dengan melakukan modifikasi terhadap proses pembelajaran agar pembelajaran tersebut lebih menarik dan membuat siswa menjadi antusias dan aktif dalam mengikuti pembelajaran (Kurniawan, 2014). Penerapan modifikasi pembelajaran yang baik dan diikuti dengan proses evaluasi yang baik, akan berdampak positif terhadap hasil belajar siswa (Priakusuma, Hasyim, dan Husin, 2012). 
Berdasarkan hasil pengamatan pada saat pembelajaran pendidikan jasmani, olahraga, dan kesehatan di SMP Negeri 1 Krejengan Probolinggo terutama pada materi permainan bolavoli masih kurang efektif, karena guru hanya menggunakan metode ceramah dan demonstrasi, selanjutnya siswa melakukan tugas gerak dan bermain sendiri. Akibatnya banyak siswa mengalami kejenuhan dan kurang aktif saat mengikuti pembelajaran pendidikan jasmani, olahraga dan kesehatan. Akhirnya yang terjadi di lapangan hanya beberapa siswa saja yang melakukan aktifitas pembelajaran bolavoli, sedangkan siswa yang tidak suka permainan bolavoli cenderung pasif.

Maka dari itu melalui penelitian ini, perlu dilakukan suatu alternatif pemecahan masalah yang terjadi dengan cara memodifikasi permainan bolavoli yang memungkinkan semua siswa ikut dalam pembelajaran permainan bolavoli dan diharapkan ada suatu perubahan yang membuat pembelajaran semakin menarik dan siswa menjadi antusias untuk mengikuti pembelajaran pendidikan jasmani, olahraga dan kesehatan khususnya saat materi permainan bolavoli.

Modifikasi yang diberikan dalam pembelajaran pendidikan jasmani, olahraga dan kesehatan materi bolavoli ini dirancang untuk meningkatkan hasil belajar siswa dalam mengikuti mata pelajaran pendidikan jasmani, olahraga dan kesehatan. Oleh karena itu perlu dilakukan penelitian dalam pembelajaran bolavoli melalui pendekatan modifikasi karena apabila menggunakan peraturan yang sesungguhnya pada saat proses pembelajaran berlangsung siswa tidak tertarik, bosan, kurang variatif dan tidak gembira. Sehingga apa yang menjadi tujuan terpenting mata pelajaran pendidikan jasmani, olahraga dan kesehatan belum sepenuhnya terpenuhi dikarenakan siswa sudah tidak minat untuk melakukan aktifitas gerak.

Berdasarkan uraian latar belakang masalah diatas peneliti akan melakukan penelitian dengan judul "Penerapan Modifikasi Permainan Bolavoli Terhadap Hasil Belajar Siswa Dalam Pembelajaran Pendidikan Bolavoli Studi Pada Siswa Kelas VIII-C SMP Negeri 1 Krejengan Probolinggo".

\section{METODE}

Jenis penelitian yang digunakan adalah penelitian tindakan (action research). Penelitian tindakan adalah cara suatu kelompok atau seseorang 
dalam mengorganisasi suatu kondisi sehingga mereka dapat mempelajari pengalaman mereka dan membuat pengalaman mereka dapat diakses oleh orang lain (Sukardi, 2013).Model yang dikembangkan oleh Kurt Lewin didasarkan atas konsep pokok bahwa penelitian tindakan terdiri dari empat komponen pokok yang juga menunjukkan langkah, yaitu:1) perencanaan atau planning, 2) tindakan atau acting,3) pengamatan atau observing, dan, 4)refleksi atau reflecting.Hubungan antara keempat komponen tersebut menunjukkan sebuah siklus atau kegiatan berulang (Suharsimi, 2013).

Instrumen yang akan digunakan dalam penelitian adalah instrumen evaluasi yang digunakan dalam pembelajaran berupa tes hasil belajar bolavoli yang meliputi aspek psikomotortes ini digunakan untuk mengetahui keterampilan gerak siswa terhadap teknik dasar dalam permainan bolavoli meliputi: passing bawah (selama 60 detik), passing atas (selama 60 detik), servis bawah, servis atas. Aspek Kognitiftes ini digunakan untuk mengetahui kemampuan siswa terhadap materi pembelajaran bolavoli.

Dalam penelitian ini menggunakan analisis deskriptif, untuk analisis persentase digunakan rumus persentase, yaitu:

Keterangan:

$$
P=\frac{S}{N} \times 100 \%
$$

$\mathrm{P}=$ Persentase penguasaan tiap aspek

$\mathrm{S}=$ Jumlah skor perolehan untuk setiap aspek

$\mathrm{N}=$ Jumlah skor

Untuk menghitung rata-rata prosentase untuk setiap siklus digunakanrumus rata-rata sebagai berikut:

$$
\text { Rata }- \text { rata }=\frac{\text { Sprosentasepenguasaantiapaspek }}{\text { Saspek keterampilan }}
$$

(dalam Suraji, 2013).

Untuk menentukan ketuntasan secara klasikal, menggunakan rumus dari Depdikbud dalam (Karim, 2010), sebagai berikut:

$$
\mathrm{KB}=\frac{\text { Jumlah Siswa Tuntas }}{\text { Jumlah Keseluruhan Siswa }} \times 100 \%
$$

Keterangan:KB : Ketuntasan Belajar 


\section{HASIL DAN PEMBAHASAN}

Data penelitian yang diperoleh adalah data hasil belajar siswa-siswi pada aspek kognitif dan aspek psikomotor yang disajikan dalam dua siklus sebagai berikut:

Pre-test ini biar peneliti mengetahui dengan mudah aspek kognitif (pengetahuan) dan aspek psikomotor (keterampilan gerak) siswa, sebelum diberikan pemahaman terkait teknik dasar penerapan modifikasi permainan bolavoli. Hasil dari pre-test dapat dilihat pada tabel dibawah ini:

Tabel 1. Hasil Pre-Test Pengetahuan Siswa (Aspek Kognitif)

\begin{tabular}{|l|l|l|l|l|l|}
\hline $\begin{array}{l}\text { Rentang } \\
\text { Nilai }\end{array}$ & Keterangan & Kriteria & $\begin{array}{l}\text { Jumlah } \\
\text { Siswa-Siswi }\end{array}$ & \multicolumn{2}{|l|}{ Persentase } \\
\hline $90-100$ & Sangat Baik & Tuntas & 4 & $13,40 \%$ & \multirow{2}{*}{$16,70 \%$} \\
\hline $75-89$ & Baik & Tuntas & 1 & $3,30 \%$ & \\
\hline $70-74$ & Cukup & Belum Tuntas & 4 & $13,40 \%$ & \multirow{2}{*}{$83,30 \%$} \\
\hline $65-69$ & Kurang Baik & Belum Tuntas & 2 & $6,60 \%$ & \\
\hline$<65$ & Tidak Baik & Belum Tuntas & 19 & $63,30 \%$ & \\
\cline { 1 - 2 } & & $\mathbf{3 0}$ & $\mathbf{1 0 0 \%}$ & \\
\hline
\end{tabular}

Berdasarkan hasil pre-test aspek kognitif dalam pembelajaran penerapan modifikasi permainan bolavoli, siswa yang tuntas sebanyak 5 orang atau $16,70 \%$. Sedangkan siswa yang belum tuntas sebanyak 25 orang atau $83,30 \%$.

Tabel 2.Hasil Pre-TestAspek Psikomotor (Passing Bawah)

\begin{tabular}{|c|c|c|c|c|c|c|}
\hline \multicolumn{2}{|c|}{$\begin{array}{l}\text { Rentang Nilai } \\
\text { Passing Bawah }\end{array}$} & \multirow{3}{*}{$\begin{array}{l}\text { Keterangan } \\
\text { Sangat Baik }\end{array}$} & \multirow{3}{*}{$\begin{array}{l}\text { Kriteria } \\
\text { Tuntas } \\
\end{array}$} & \multirow{2}{*}{$\begin{array}{l}\text { Jumlah } \\
\text { Siswa- } \\
\text { Siswi } \\
\end{array}$} & \multirow{2}{*}{\multicolumn{2}{|c|}{ Persentase }} \\
\hline \multirow{2}{*}{$\begin{array}{l}\text { Putra } \\
>47\end{array}$} & \multirow{2}{*}{$\begin{array}{l}\text { Putri } \\
>45\end{array}$} & & & & & \\
\hline & & & & 1 & $3,30 \%$ & \\
\hline $40-46$ & $37-44$ & Baik & Tuntas & 0 & $0,00 \%$ & $3,50 \%$ \\
\hline $27-39$ & $21-36$ & Cukup & Belum Tuntas & 11 & $36,70 \%$ & \\
\hline $17-26$ & $13-20$ & Kurang Baik & Belum Tuntas & 7 & $23,30 \%$ & $96,70 \%$ \\
\hline$<16$ & $<12$ & Tidak Baik & Belum Tuntas & 11 & $36,70 \%$ & \\
\hline \multicolumn{4}{|c|}{ JUMLAH } & 30 & $100 \%$ & \\
\hline
\end{tabular}

Berdasarkan hasil pre-test aspek psikomotor dalam pembelajaran penerapan modifikasi permainan bolavoli, siswa yang tuntas sebanyak 1 
orang atau 3,30\%. Sedangkan siswa yang belum tuntas sebanyak 29 orang atau $96,70 \%$.

Tabel 3.Hasil Pre-TestAspek Psikomotor (Passing Atas)

\begin{tabular}{|c|c|c|c|c|c|c|}
\hline \multicolumn{2}{|c|}{$\begin{array}{l}\text { Rentang Nilai } \\
\text { Passing Atas }\end{array}$} & \multirow{3}{*}{$\begin{array}{l}\text { Keterangan } \\
\text { Sangat Baik }\end{array}$} & \multirow{3}{*}{$\begin{array}{l}\text { Kriteria } \\
\text { Tuntas }\end{array}$} & \multirow{2}{*}{$\begin{array}{l}\text { Jumlah } \\
\text { Siswa- } \\
\text { Siswi }\end{array}$} & \multirow{2}{*}{\multicolumn{2}{|c|}{ Persentase }} \\
\hline \multirow{2}{*}{$\begin{array}{l}\text { Putra } \\
>56\end{array}$} & \multirow{2}{*}{\begin{tabular}{|l|} 
Putri \\
$>54$
\end{tabular}} & & & & & \\
\hline & & & & 0 & $0,00 \%$ & \multirow{2}{*}{$0,00 \%$} \\
\hline $43-55$ & $37-53$ & Baik & Tuntas & 0 & $0,00 \%$ & \\
\hline $31-42$ & $20-36$ & Cukup & Belum Tuntas & 0 & $0,00 \%$ & \multirow{3}{*}{$100 \%$} \\
\hline $20-30$ & $10-19$ & Kurang Baik & Belum Tuntas & 12 & $40,00 \%$ & \\
\hline$<19$ & $<9$ & Tidak Baik & Belum Tuntas & 18 & $60,00 \%$ & \\
\hline \multicolumn{4}{|c|}{ JUMLAH } & 30 & \multicolumn{2}{|l|}{$100 \%$} \\
\hline
\end{tabular}

Berdasarkan hasil pre-test aspek psikomotor dalam pembelajaran penerapan modifikasi permainan bolavoli, siswa yang tuntas sebanyak 0 orang atau $0,00 \%$. Sedangkan siswa yang belum tuntas sebanyak 30 orang atau $100 \%$.

Tabel 4.Hasil Pre-TestAspek Psikomotor (Servis Bawah)

\begin{tabular}{|c|c|c|c|c|c|c|}
\hline \multicolumn{2}{|c|}{$\begin{array}{l}\text { Rentang Nilai } \\
\text { Servis Bawah }\end{array}$} & \multirow{3}{*}{$\begin{array}{l}\text { Keterangan } \\
\text { Sangat Baik }\end{array}$} & \multirow{3}{*}{$\begin{array}{l}\text { Kriteria } \\
\text { Tuntas }\end{array}$} & \multirow{2}{*}{$\begin{array}{l}\text { Jumlah } \\
\text { Siswa- } \\
\text { Siswi } \\
\end{array}$} & \multirow{2}{*}{\multicolumn{2}{|c|}{ Persentase }} \\
\hline \multirow{2}{*}{$\begin{array}{l}\text { Putra } \\
>25\end{array}$} & \multirow{2}{*}{\begin{tabular}{|l|} 
Putri \\
$>24$
\end{tabular}} & & & & & \\
\hline & & & & 0 & $0,00 \%$ & \multirow{2}{*}{$0,00 \%$} \\
\hline $21-24$ & $19-23$ & Baik & Tuntas & 0 & $0,00 \%$ & \\
\hline $15-20$ & $10-18$ & Cukup & Belum Tuntas & 12 & $40,00 \%$ & \multirow{3}{*}{$100 \%$} \\
\hline $10-14$ & $5-9$ & Kurang Baik & Belum Tuntas & 12 & $40,00 \%$ & \\
\hline$<9$ & $<4$ & Tidak Baik & Belum Tuntas & 6 & $20,00 \%$ & \\
\hline \multicolumn{2}{|c|}{ JUMLAH } & & & 30 & $100 \%$ & \\
\hline
\end{tabular}

Berdasarkan hasil pre-test aspek psikomotor dalam pembelajaran penerapan modifikasi permainan bolavoli, siswa yang tuntas sebanyak 0 orang atau $0.00 \%$. Sedangkan siswa yang belum tuntas sebanyak 30 orang atau $100 \%$ 
Tabel 5.Hasil Pre-TestAspek Psikomotor (Servis Atas)

\begin{tabular}{|c|c|c|c|c|c|c|}
\hline \multicolumn{2}{|c|}{$\begin{array}{l}\text { Rentang Nilai } \\
\text { Servis Atas }\end{array}$} & \multirow{3}{*}{$\begin{array}{l}\text { Keterangan } \\
\text { Sangat Baik }\end{array}$} & \multirow{3}{*}{$\begin{array}{l}\text { Kriteria } \\
\text { Tuntas }\end{array}$} & \multirow{3}{*}{$\begin{array}{l}\text { Jumlah } \\
\text { Siswa- } \\
\text { Siswi } \\
0\end{array}$} & \multirow{2}{*}{\multicolumn{2}{|c|}{ Persentase }} \\
\hline \multirow{2}{*}{$\begin{array}{l}\text { Putra } \\
>25\end{array}$} & \multirow{2}{*}{\begin{tabular}{|l} 
Putri \\
$>23$
\end{tabular}} & & & & & \\
\hline & & & & & $0,00 \%$ & \\
\hline $21-26$ & $18-22$ & Baik & Tuntas & 1 & $3,30 \%$ & $3,50 \%$ \\
\hline $15-20$ & $11-17$ & Cukup & Belum Tuntas & 9 & $30,00 \%$ & \\
\hline $8-14$ & $7-10$ & Kurang Baik & Belum Tuntas & 8 & $26,70 \%$ & $96,70 \%$ \\
\hline$<7$ & $<6$ & Tidak Baik & Belum Tuntas & 12 & $40,00 \%$ & \\
\hline \multicolumn{4}{|c|}{ JUMLAH } & 30 & $100 \%$ & \\
\hline
\end{tabular}

Berdasarkan hasil pre-test aspek psikomotor dalam pembelajaran penerapan modifikasi permainan bolavoli, siswa yang tuntas sebanyak 1 orang atau 3,30\%. Sedangkan siswa yang belum tuntas sebanyak 29 orang atau $96,70 \%$.

Dapat disimpulkan dari hasil pre-test dari aspek kognitif dan aspek psikomotor. Bahwa yang mencapai ketuntasan dari aspek kognitif sebesar $16,70 \%$ dan yang belum tuntas sebesar $83,30 \%$. Sedangkan dari aspek psikomotor sebesar $1.65 \%$ yang tuntas dan yang belum tuntas sebesar $98,35 \%$, bisa dilihat pada diagram dibawah ini:

\section{Grafik 1. Hasil Pre-Test Aspek Kognitif dan Aspek Psikomotor}

\section{Aspek Kognitif dan Aspek Psikomotor}

\begin{tabular}{|c|c|c|c|c|}
\hline $120,00 \%$ & & & & \\
\hline $100,00 \%$ & & & & \\
\hline $80,00 \%$ & & & & \\
\hline $60,00 \%$ & & & & \\
\hline $40,00 \%$ & & & & \\
\hline $20,00 \%$ & 7 & & & \\
\hline $0,00 \%$ & $\begin{array}{c}\text { Aspek } \\
\text { Kognitif } \\
\text { (tuntas) }\end{array}$ & $\begin{array}{l}\text { Aspek } \\
\text { Kognitif } \\
\text { (belum } \\
\text { tuntas) }\end{array}$ & $\begin{array}{c}\text { Aspek } \\
\text { Psikomoto } \\
\text { r (tuntas) }\end{array}$ & $\begin{array}{c}\text { Aspek } \\
\text { Psikomoto } \\
\text { r (belum } \\
\text { tuntas) }\end{array}$ \\
\hline $\begin{array}{l}\square \text { Aspek Kognitif dan Aspek } \\
\text { Psikomotor }\end{array}$ & $16,70 \%$ & $83,30 \%$ & $1,65 \%$ & $98,35 \%$ \\
\hline
\end{tabular}


Setelah dilaksanakan pembelajaran permainan bolavoli melalui penerapan modifikasi permainan bolavoli terhadap hasil belajar melalui siklus I dan siklus II. Perbandingan dan peningkatan dari 2 tindakan dapat dilihat pada tabel dibawah ini:

Tabel 6. Perbandingan Hasil Belajar Siswa Aspek Kognitif

\begin{tabular}{|l|l|l|}
\hline \multicolumn{3}{|l|}{ Hasil Belajar Siswa (Aspek Kognitif) } \\
\hline Siklus I & Siklus II & Peningkatan \\
\hline $16,70 \%$ & $76,70 \%$ & $22,93 \%$ \\
\hline
\end{tabular}

\section{Grafik 2. Perbandingan Hasil Belajar Siswa Aspek Kognitif}

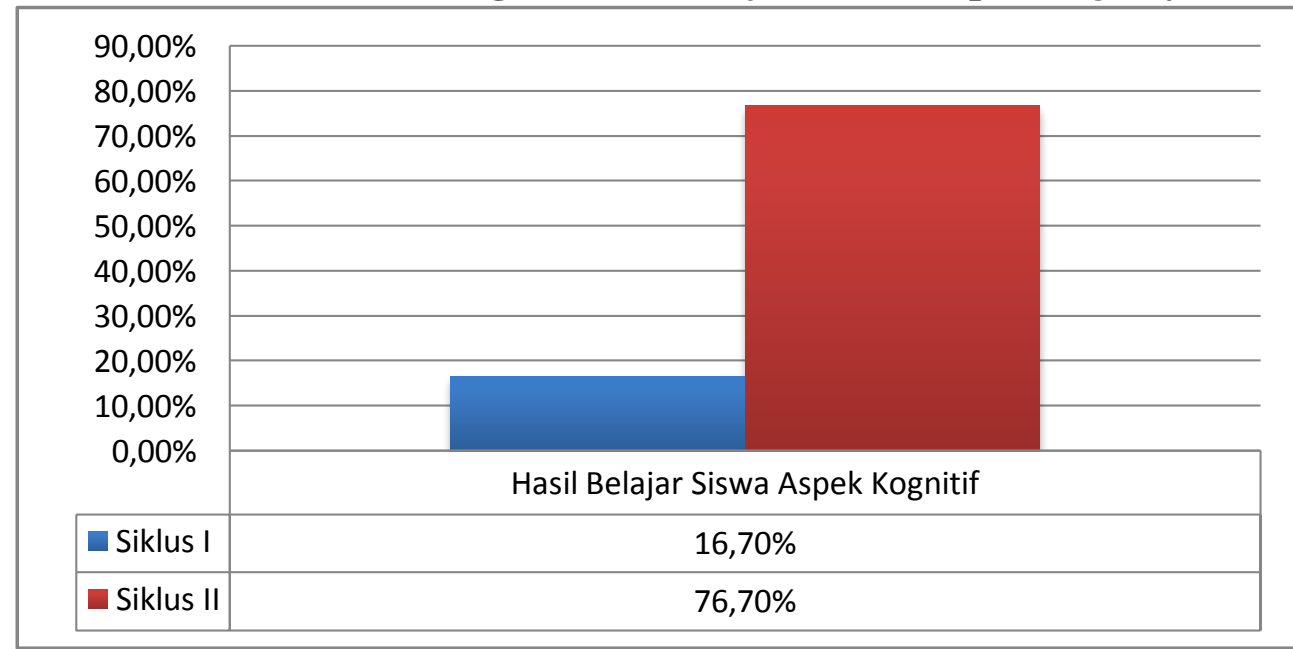

Tabel 7. Perbandingan Hasil Belajar Siswa Aspek Psikomotor

\begin{tabular}{|l|l|l|}
\hline \multicolumn{3}{|l|}{ Hasil Belajar Siswa (Aspek Psikomotor) } \\
\hline Siklus I & Siklus II & Peningkatan \\
\hline $17,50 \%$ & $70,00 \%$ & $20,92 \%$ \\
\hline
\end{tabular}


Grafik 3. Perbandingan Hasil Belajar Siswa Aspek Psikomotor

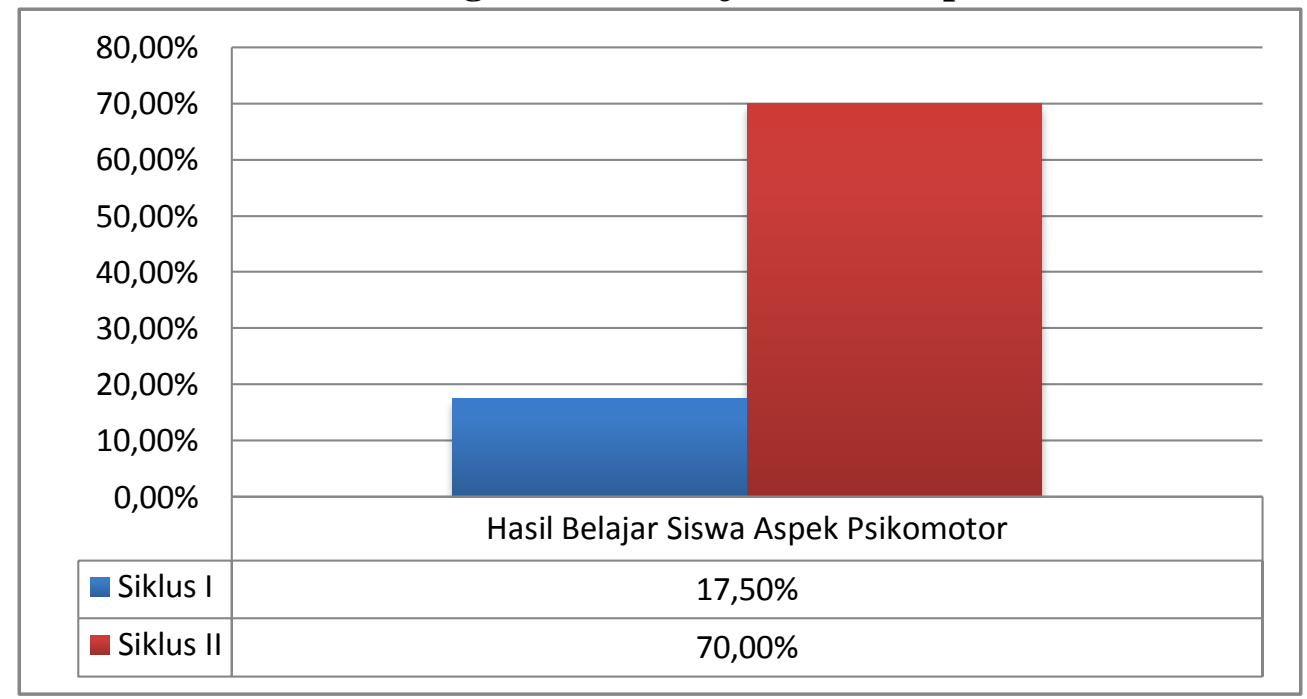

Penelitian tindakan kelas yang telah dilaksanakan dalam prosespembelajaran dengan menerapkan modifikasi permainan bolavoli terhadap hasil belajar siswa. Untuk mengetahui adanyapeningkatan oleh peneliti dilakukan tes dalam 2 aspek, yaitu aspek kognitif dan aspek psikomotor. Dari hasil pre-test siswa dalam aspek kognitif sebesar 16,70\% yang sudah tuntas dan yang belum tuntas sebesar $83,30 \%$. Sedangkan dalam aspek psikomotor sebesar $95,90 \%$ yang belum tuntas dan yang sudah tuntas sebesar 4,10\%. Hasil ini masih belum termasuk kriteria tuntas atau baik.

Pada tindakan siklus I mengalami peningkatanpembelajaran terutama dalam aspek psikomotor siswa, dibandingkan dari hasil pre-test siswa. Dari hasil siklus I dalam aspek kognitif sebesar 16,70\% yang tuntas dan yang belum tuntas sebesar $83,30 \%$. Sedangkan dalam aspek psikomotor sebesar $17,50 \%$ yang tuntas dan yang belum tuntas sebesar $82,50 \%$. Pada tindakan siklus II mengalami peningkatan pembelajaran, baik dalam aspek kognitif maupun aspek psikomotor. Dilihat dari hasil siklus II dalam aspek kognitif sebesar 76,70\% yang tuntas dan yang belum tuntas sebesar 23,30\%. Sedangkan dalam aspek psikomotor sebesar $70,00 \%$ yang tuntas dan yang belum tuntas sebesar 30,00\%.

Menurut penelitihambatan dan kendala yang ditemukan pada siklus I selama proses pembelajaran penerapan modifikasi permainan bolavoli, yaitu: siswa kurang bersemangat, tidak teratur atau ramai saat melakukanaspek 
psikomotor, masih merasa kesulitan dalam melakukan passing atas, bawah dan servis atas, bawah. Karena belum pernah dipelajari dengan menggunakan alat/media modifikasi (bola plastik).Untuk mengurangi hambatan dan kendala yang muncul pada saat tindakan siklus I, peneliti merencanakan tindakan siklus II. Dari hasil tindakan siklus II dalam aspek kognitif sebesar 76,70\% atau 23 orang yang tuntas dan yang belum tuntas sebesar 23,30\% atau 7 orang. Sedangkan dalam aspek psikomotor sebesar $70,00 \%$ atau 21 orang yang tuntas dan yang belum tuntas sebesar $30,00 \%$ atau 9 orang.

Pada tindakan siklus II mengalami peningkatan pembelajaran penerapan modifikasi permainan bolavoli dilihat dari data pada siklus I, siswa yang tuntas hanya 5 siswa dalam aspek kogintif maupun aspek psikomotor. Setelah ada tindakan pada siklus II ada 23 siswa yang tuntas dalam aspek kognitif dan siswa yang tuntas dalam aspek psikomotor ada 21 siswa. Peningkatan dari siklus I ke siklus II mencapai 22,93\% dalam aspek kognitif (pengetahuan) dan peningkatan dalam aspek psikomotor (kemampuan gerak) mencapai 20,92\%. Dari data tersebut peneliti menyimpulkan pembelajaran yang sudahdilaksanakan selalu mengalami perubahan ke arah yang lebih baik, itu ditandai adanya peningkatanpengetahuan dan kemampuan gerak siswa terhadap modifikasi permainan bolavoli dari setiap pertemuan pembelajaran melalui penerapan modifikasi permainan bolavoli.

\section{SIMPULAN}

Dari hasil penelitian yang telah dilakukan dapat disimpulkan, bahwapenerapan modifikasi permainan bolavoli dapat meningkatakan hasil belajar siswa kelas VIII-C SMP Negeri 1 Krejengan Probolinggo pada materi permainan bolavoli. Hal ini dapat dilihat dari peningkatan siklus I ke siklus II dalam aspek kognitif sebesar 22,93\% dan jumlah siswa yang tuntas dari 5 siswa menjadi 23 siswa. Sedangkan peningkatan dalam aspek psikomotor sebesar 20,92\% dan jumlah siswa yang tuntas dari 5 siswa menjadi 21 siswa.

Saran yang dapat disampaikan sebagai pertimbangan untuk meningkatkan pembelajaran pendidikan jasmani, olahraga dan kesehatan khususnya adalahsupaya mendapatkan hasil belajar yang tinggi, maka perlu memperhatikan alat/media belajar. Karena alat/media merupakan salah satu faktor penunjang kesuksesan hasil belajar siswa.Sebaiknya guru penjasorkes 
menerapkan modifikasi permainan bolavoli. Karena berdasarkan penelitian yang saya lakukan terbukti siswa antusias mengikuti dan dapat meningkatkan hasil belajar siswa dalam mengikuti pelajaran penjasorkes.

\section{DAFTAR PUSTAKA}

Arikunto, Suharsimi. 2013. Prosedur Penelitian Suatu Pendekatan Praktik. Jakarta: Rineka Cipta.

Bahagia, Yoyo dan Mujianto, Sufyar. 2009. Fasilitas dan Perlengkapan Penjas. Fakultas Pendidikan Olahraga dan Kesehatan, Jurusan Pendidikan Olahraga: Universitas Pendidikan Indonesia.

Karim, Zainul. 2010. Upaya Peningkatan Kemampuan Jumping Service BolaVoli Melalui Latihan Pull-Up Pada Siswa PutraKelas VIII SMP Negeri 1 Besuk ProbolinggoTahun Pelajaran 2009/2010. Skripsi yang tidak diterbitkan. Malang: IKIP Budi Utomo Malang.

Kurniawan, D. 2014.Pengaruh Modifikasi Permainan Bolavoli terhadap Kerjasama Siswa pada Pembelajaran Pendidikan Jasmani, Olahraga dan Kesehatan (Studi pada siswa kelas X Boga 1 SMKN 3 Probolinggo). Skripsi yang tidak diterbitkan. Surabaya: UNESA.

Purwanto, Yuli. 2011. Model Pembelajaran Pendidikan Jasmani ModifikasiPermainan Bola Tangan Melalui PendekatanLingkungan Luar Sekolah Pada Siswa Kelas VSD Negeri 02 Banaran Kecamatan GrabagKabupaten Magelang. Skripsi yang tidak diterbitkan. Semarang: UNNES.

Priakusuma, A., Hasyim, A., dan Husin, S. 2012. Penerapan Modifikasi Alat Pembelajaran Pendidikan Jasmani Untuk Peningkatan Hasil Belajar Atletik Nomor Lempar Cakram Pada Siswa Kelas VIII SMP Muhammadiyah 1 Pringsewu. (Online), (https://media.neliti.com /media/publications/192225, diakses 30 oktober 2017).

Syamsudin, Haetami, M., dan Hidasari, F. P. 2016. Upaya Meningkatkan Hasil Belajar Keterampilan Menggiring Bola Melalui Media Pembelajaran Bola Plastik di Sekolah Dasar. (Online), 
(https://media.neliti.com/media/publications/217093, diakses 30 oktober 2017).

Sukardi. 2013. Metodologi Penelitian Pendidikan Kompetensi dan Praktiknya. Jakarta: PT Bumi Aksara.

Suraji. 2013.Peningkatan Hasil Belajar Permainan Bola Voli Melalui Metode Kelompok Bermain pada Siswa Kelas IV SD Negeri 02 Pantianom Kecamatan Bojong Kabupaten Pekalongan. Skripsi yang tidak diterbitkan. Semarang: UNNES.

Saputra, Iwan. 2015. Modifikasi Media Pembelajaran Pendidikan Jasmani Sekolah Dasar. Jurnal Ilmu Keolahragaan, Vol. 14 (2) pp. 35-41. 